\title{
CAPITAL STRUCTURE, WORKING CAPITAL MANAGEMENT AND POTENTIAL GROWTH OF A BUSINESS: THE CASE OF THE SRI LANKAN STOCKBROKING INDUSTRY
}

\author{
Chamil W. Senarathne ${ }^{1 *}$ and Viraj Malawana ${ }^{2}$ \\ ${ }^{1}$ School of Economics, Wuhan University of Technology, China \\ E-mail: chamil@whut.edu.cn \\ ${ }^{2}$ Strategic Business Innovator (Pvt) Ltd, Colombo, Sri Lanka \\ E-mail: viraj@sbisl.lk
}

\begin{abstract}
The objective of this paper is to examine the financial and strategic implications of regulatory restrictions for working capital management of firms operating in the stockbroking industry. The present regulatory frameworks require banks and other financial services sector firms to have more equity capital in the capital base, without regard to the financial and operating characteristics of the firms. Based on the Sri Lankan stockbroking industry, this paper shows how the return on equity deteriorates and potential growth restricted, when the regulations require firms to deduct certain assets from the capital base to meet the minimum capital requirements. The results show that the potential growth and return on equity reduce substantially after compliance with the regulation. Further, the regulation restricts a firm's attempt to diversify the collateral portfolio in the market in order to reduce the systematic risk attached to the securities in the collateral portfolio. These regulatory restrictions also add an additional stress level to corporate management to leverage the number of times of sales (sales turnover) in order to overcome the issue, which may result in overtrading. It may also create ethical issues on soliciting clients and induce them to trade in the stock market, without proper justifications.
\end{abstract}

Keywords: net capital, Basel regulation, working capital hedging, potential growth analysis, DuPont analysis, return on equity

ARTICLE INFO

Article History:

Received: 27 October 2018

Accepted: 12 March 2019

Published: 30 April 2019 


\section{INTRODUCTION}

In the recent past, the Colombo Stock Exchange (CSE) has been going through a number of market corrections and recorded a marked decline accelerated by force-selling of securities (Kadirgamar, 2012; Reuters 2011, October 19; Transparency International Sri Lanka 2012). Further, the direction (SEC/LEG/12/01/10) issued by the Securities and Exchange Commission of Sri Lanka (SEC) requiring stockbrokers to deduct debtors1 from the shareholder funds, in ascertaining adjusted net capital, had a significant impact on the performance of the stock market (Reuters, 2012). Therefore, the stock market has been driven mainly by the regulatory changes and its performance had been dependent upon these changes rather than the fundamental determinants of the stocks being traded. Usually, a stock market crisis adversely affects the market efficiency and investors tend to overreact to local as well as cross-market information during the crises periods (Lim et al., 2008). As a result, many securities trading in the stock market are highly undervalued and the prospective investors 2 are reluctant to invest due to loss of confidence in the CSE. This has occurred mainly due to investor panic and sale of shares (i.e. force-selling) to comply with the regulatory requirements. Mishkin (1992) and Leite and Cortez (2015) argue that the securities usually become highly undervalued during crises periods.

Deduction of debtors from shareholder funds, in the case of compliance, has an unnecessary burden on the operating capacity of a stockbroker as it amounts to elimination of the value of debtors from the asset base and thereby from the net asset (shareholder funds and reserves) value of the firm. As such, the credit lines obtained by a firm to finance debtors cannot be effectively utilized and the leverage allowed for financing current assets (e.g. debtors) using temporary sources of funds (e.g. bank overdraft facility) is not applicable (i.e. not utilizable). Accordingly, if a firm wishes to extend credits to its investors, it needs to increase shareholder funds (permanent capital) either by rights issue of shares, fresh issue of shares or issue of preference shares, which amounts to financing current assets (i.e. debtors) by permanent sources of capital. This practice is fully contradictory with basic principles of working capital management and is considered as a too conservative hedging; thus, leading to working capital mismatches.

1 The terms 'debtors' and 'credit extended to clients/debtors' are used interchangeably.

2 The terms 'clients' and 'investors' are also used interchangeably. 


\section{Colombo Stock Exchange}

The CSE is one of the most advanced stock exchanges in South Asia. It provides a fully automated trading platform for all registered memberswhich facilitates real time stock trading.

The CSE was incorporated under the Companies Act No. 17 of 1982 of Sri Lanka and is limited by guarantee. The operation of the CSE is licensed by the Securities \& Exchange Commission of Sri Lanka (SEC). The CSE is a mutual exchange, and has 15 full members and 16 trading members who are licensed to trade in equity and debt securities. Three members of the CSE are licensed to trade only in debt securities. All members of the CSE are authorized and licensed by the SEC to operate as corporate entities, subsidiaries of large banks or nonbank financial institutions.

The entire stock market operation system of the CSE is managed by its fully owned subsidiary, Central Depository Systems (Pvt) Limited (CDS) that acts as a clearing and settlement system facilitator for all market transactions. The CSE also regulates the compliances through a set of rules, and actively promotes the standards of corporate governance among listed companies. The CSE is involved in educating market participants on a regular basis and its network of contacts includes customers, stakeholders, issuers (such as companies, corporations and unit trusts), commercial banks, investment banks, fund managers, stockbrokers, financial advisers, market data vendors and investors.

\section{Stockbroker Crisis 2011/2012}

Since the conclusion of the civil war on 18 May 2009, the CSE displayed a remarkable growth, recording the highest daily turnover on average about 3-4 billion rupees during 2010/2011 (first half). The CSE was recognized as one of the best performing stock exchanges in the world in 2010 as its main index (ASPI) jumped by 125.2 percent. The All Share Price Index (ASPI) recorded its all-time high of 7811.8 points, achieved in February 2011. However, in the mid-2011, the regulators had realized that the market was overvalued and some adverse comments had been made by stock market analysts both in print and broadcast media about the situation. Certain media coverage had identified this situation as a 'stock bubble' on 
excessive credit given to investors in the CSE by stockbrokers. It has had a significant impact on investor confidence in the stock market and market prices had started to decline gradually towards the end of year 2011. The regulators had also realized the fact that the market was overvalued on credit purchases.

In the first half of 2012, the market was affected by net capital issue of stockbrokerage firms and a tremendous pressure had been exerted upon stockbrokers by the regulators (CSE and SEC) to reduce credit given to investors. Stockbrokerage firms and investors had incurred significant losses due to force-selling of securities of investors - who were in default of payment after the settlement period - to comply with the net capital rule. The course of being in compliant with the rule, constitutes a deduction of the entire value of debtors from the net capital under different age categories, including the difference between the cost and market value of unsettled purchase transactions in the event that the current market value is less than the purchase price as per the guidelines issued by the CSE and SEC. Consequently, the market was adversely affected by force-selling of securities and the prices of most of the counters were substantially undervalued in the market. In January 2012, the CSE and SEC finally allowed stockbrokers to extend credit up to three times of their adjusted net capital. Further, the regulators had strengthened the supervision of stockbrokers and implemented a close watch on credit risk exposures and fortnightly debtor information reporting system which was introduced to strengthen the off-site supervision of credit risk exposures. Other measures of mitigating broker credit issue include implementation of Risk Management System (RMS) and common broker back office system. Notably, the CSE was also directly affected by the world financial crisis of 2012 and declined to reach an all-time low of 4737.75 points (ASPI) in the post-war era in June 2012 (see Goudarzi \& Ramanarayanan, 2011; Freedi et al., 2012 for some international evidence on the impact of various types of economic and financial crises on stock market performance).

\section{Adjusted Net Capital and Broker Credit - The Rule}

As per the direction (SEC/LEG/12/01/10) of the SEC, stockbrokers were allowed to extend credit to investors up to a maximum of three (03) times of adjusted net capital of the stockbrokerage firms and required to 
deduct debtors from the shareholder funds in the ascertainment of net capital of the stockbrokerage firms. According to the regulation, the deduction of debtors must be made under three age categories - where the cost of debtors falling under ' $\mathrm{T}+3$ to $\mathrm{T}+30$ ' calendar days age category is excluded from deduction - provided that the cost less provisions made does not exceed the market value of securities portfolio falling under such age category. Further fifty percent $(50 \%)$ deduction is required from the cost of the debtors (net of provisions made) falling under ' $\mathrm{T}+30$ to $\mathrm{T}+120$ ' calendar days age category and hundred percent $(100 \%)$ deduction of debtors falling under 'over $\mathrm{T}+120$ ' calendar days age category.

In addition, the following were also deducted from the shareholder funds of the firm in ascertaining adjusted net capital.

1. Unsecured loans

2. Amount due from related parties

3. Assets which are doubtful for collection less provision made

4. Deferred expenses and / or intangible assets

5. Contingent liabilities

6. Excess of cost over market value of member firm's portfolio

7. $50 \%$ of the carrying value of fixed assets.

The objective of this research was to examine the financial and strategic implications of regulatory restrictions for working capital management of firms operating in the stockbroking industry. This research was handled using the case study methodology from a sample of fifteen stockbrokerage firms. The analysis showed that the potential growth and return on equity is substantially reduced when the stockbrokerage firms finance current assets (i.e. debtors) through long-term sources of funds (i.e. equity capital). The remainder of this paper is organized as follows. Section two reviews the existing literature and section three provides the conceptual framework. Section four carries an extensive analysis of the case and section five discusses the limitations of the study. Section six concludes the paper. 


\section{LITERATURE REVIEW}

A stockbrokerage business or a similar operation (e.g. margin trading) by a firm in the financial services industry can be identified as a firm operating in an oligopolistic market (Toniolo et al., 2003; Yin, 2004; Shubik, 2016; Fah \& Ariff, 2017; Chung \& Mohd, 2018). A stockbrokerage business carried out with a profit motive may employ its own financial and business strategiesso as to maximize the return on investment (equity) - commensurate with the risk accepted by its ordinary shareholders. Thus, the regulatory changes must be in line with the primary financial objective of a stockbrokerage firm (i.e. maximization of the wealth of its ordinary shareholders). Acceptable level of leverage is essential for the potential growth of a business. A potential problem that might arise in the course of a business operation-when adhering to the regulatory requirements - is the agency problem. Equity holders infuse capital with the view of receiving a sufficient return on the capital invested. As such, a stressful task is entrusted with firm managers to manage shareholder funds more effectively and efficiently, within the regulatory framework.

Titman and Wessels (1988) argue that 'equity-controlled firms have a tendency to invest suboptimally to expropriate wealth from the firm's bondholders. The cost associated with this agency relationship is likely to be higher for firms in growing industries, which have more flexibility in their choice of future investments. Expected future growth should thus be negatively related to long-term debt levels. Myers ( ), however, noted that this agency problem is mitigated if the firm issues short-term rather than long-term debt. This suggests that short-term debt ratios might actually be positively related to growth rates if growing firms substitute shortterm financing for long-term financing'. This suggests that a firm could enhance the potential wealth of equity by appropriately managing shortterm and long-term debt, so as to increase the potential growth of a firm. Eventually, this is achieved at the expense of owners' capital because the firm must compensate ${ }^{3}$ the equity holders for increased financial leverage, in the case of debt financing. The regulatory involvement on this exercise (i.e. regulator determines working capital mix) may have implications for the growth of a business. Up to a certain level, there should be a positive association between value of debt and return on capital employed (Titman, 2002). Abor (2005) and many others find that there is a positive association

3 For the risk premium demanded by equity holders on additional financial risk. 
between short-term debt and return on equity ${ }^{4}$. Chadha and Sharma (2015) show that the factors such as size, tangibility, sales growth, asset turnover and ownership structure significantly determine the financial performance of firms in the Indian manufacturing sector. On the other hand, a number of scholars demonstrate that the mode of working capital financing significantly impacts on firm profitability (see e.g. Iqbal \& Zhuquan, 2015; Pais \& Gama, 2015; Afrifa \& Padachi, 2016; Lyngstadaas \& Berg, 2016; Muhammad et al., 2016; Samiloglu \& Akgün, 2016; Singh et al., 2017). Working capital financing and its impact on profitability varies between industries and working capital management policies should be designed based on industry specific differences (see Padachi, 2006; Afza \& Nazir, 2008). However, the scholars do not attempt to understand how conservative working capital financing policies could impact the return on current assets and equity, especially with reference to the stockbroking industry.

Researchers show that improper working capital policies are negatively related to profitability of firms (see Carpenter \& Johnson, 1983; Afza \& Nazir, 2007) and contemporary firms tend to rely more on short-term sources of working capital financing to be more flexible in dynamic business environments (see DeGeest et al., 2016). Scholars namely Padachi (2006), Jose et al. (1996), Chiou et al. (2006) and Kieschnich et al. (2011) show that business variables such as profitability and business cycle are related to working capital. Also, a number of scholars such as Schiff and Lieber (1974), Smith (1980), Kim and Chung (1990), Wang (2002), Enqvist et al. (2014) and Aktas et al. (2015) show that better working capital management increases the financial performance and market value of firms (i.e. shareholder value).

On the other hand, equity based permanent sources of capital (including preference shares if issued) can be considered as expensive sources of funds whereas the return on current assets (e.g. debtors) financed by permanent sources of capital is lower than the expected rate of return on permanent capital (see example $1 \& 2$ ). As such, the firm is losing on application of these strategies in order to comply with the regulation. It is not justifiable to suggest that the interest rate on credit (debtors) could be increased to compensate the working capital mismatches identified above (a detailed analysis is provided in section four).

4 He also finds a positive association between total debt and return on equity. 


\section{A SIMPLE FRAMEWORK}

\section{Deduction of Total Value of Debtors from Net Capital}

Assume that firm is operating with amount of current assets ${ }^{5}$ (book value) in the stockbroking industry. The firm has no debt $\left(D_{i}\right)$ in the capital structure because the short-term (or even long-term) debt capital is not considered for the purpose extending credit (temporary working capital) to its clients. As such, the firm needs to finance temporary working capital requirements by permanent sources of capital (in this case, equity capital). The equity holders (the owners of the firm) expect a return on their capital invested as,

$$
E\left(R_{i}\right)=R_{f}+\beta_{u m}\left(R_{m}-R_{f}\right)
$$

Where $E\left(R_{i}\right)$ is the expectation of return and $R_{f}$ is the risk free rate of return. $\beta_{u m}$ is the unlevered market beta of firm $i$. Since all stockbrokerage firms in Sri Lanka are not listed, lever the unlevered beta of firm $i$ in the sense of Miller (1977) which yields,

$$
\beta_{e m}=\beta_{u m}+\left[\left(\beta_{u m}-\beta_{d}\right)+\left(R_{d} T\right) /\left(R_{m}-R_{p}\right)\right] D_{i} / E_{i}
$$

Where $\beta_{e m}$ is the levered beta and $\beta_{d}$ is the debt beta. $R_{d} T$ is multiplication outcome of the interest rate and tax rate respectively. $D$ stands for debt and $E$ stands for equity. Finally, this attempt leaves the firm with $E_{s}=0$ where $E_{s}$ is the expectation of tax shield (benefit) attributable to equity ${ }^{6}$ and $\beta_{e m}=\beta_{u m}$. There is no reason to maintain debt capital (short or long-term) in this firm's capital structure because there is no use of debt for the purpose of business operation.

5 Assume a negligible amount of tangible fixed assets, already financed. All most all stockbrokers in Sri Lanka do not have owned premises and are operating in rented premises or premises belongs to parent companies (e.g. stockbroking firms of banking arms). Hence, this current asset sustainably reflects debtors advanced.

6 By substituting D with 0 . 


\section{Deduction of Credit Exposures ${ }^{7}$ from Net Capital}

Now consider this issue from the regulator's point of view. Assume that the value of asset (i.e. debtors) $A_{i}^{8}$ is backed by amount of collaterals, whose values vary based on both systematic and collateral specific risk factors. Assume that $A_{i}<\left[C_{i}-\left(C_{i} * w_{t o t}\right)\right]$ and firm's net asset value is positive and substantially greater than the aggregate value of credit exposures (i.e. $F_{e}$ as below). Let $w_{t o t}$ be the total risk weight of collateral portfolio and, $w_{s}$ and $w_{f}$ be the systematic and collateral specific risk weights, in which, $w_{s}$ is common to both owners (shareholders of stockbrokerage firm) and debtors (i.e. clients enjoying broker credits) ${ }^{10}$ but has separate monetary effect on the economy. Of course, $w_{f}$ is relevant for stockbroker equity owners and a compensation for $w_{s}$ is required from the stockbroking industry ${ }^{11}$ (i.e. market) because the stockbrokerage firms do not have the authority to manage the collateral specific risk by appropriately diversifying the collateral portfolios. Unless a fore-selling requirement arises, the collateral portfolio can only be moved (i.e. trade to manage) at the sole discretion of the client. Debtors have already pledged their collateral portfolios on credit obtained, so that the stockbrokerage firm could ensure that cost of credit lines do not exceed the realizable value of the collateral portfolios. If the market prices of the securities portfolios decline, stockbrokerage firm must sell the securities portfolios to recover the debtors or request the clients to deposit money into the share trading account.

The managers should minimize the risk of $w_{s}$ by appropriately evaluating and obtaining diversified collateral portfolios from the clients ${ }^{12}$. This is again, a matter of concern as regulator does not allow firms to finance its debtors by short or long-term debt capital or to obtain different forms of collaterals other than the stock portfolios bought by the clients. The risk consideration for both regulator and stockbrokerage firms is the excess of

7 Excess of cost over market value of securities portfolios.

8 In this case, the value of securities portfolio of the client/s.

9 The collaterals would also be a part of securities portfolio of the client/s (this is also called debt portfolio)

10 This is particularly because the collateral becomes the securities bought by clients, unless the firm obtains other forms of securities (in line with regulatory framework) such as Lands, deposits etc. where they have their own markets. However, the CSE and SEC regulations do not permit stockbrokers to obtain collaterals other than listed securities (equities or debt securities) collateral.

11 Since stockbrokerage firms are not listed in Sri Lanka.

12 Note that the collaterals will also be the debt securities portfolio and the regulator does not allow the stockbrokerage firms to obtain securities other than stock portfolio bought by the client. 
cost over market value of collateral portfolio (i.e. $A_{i}>C_{i}$ ). The amount of debtors (i.e. default due to inability to manage collateral portfolio) that should be financed by equity $\left(F_{e}\right)$ would then be $F_{e}=A_{i}<\left[C_{i}-\left(C_{i}{ }^{*} w_{t o t}\right)\right]$ and the implied tax benefit foregone ${ }^{13}$ (reflected in the WACC, if financing debtors by way of debt capital is allowed) on the application of above rule would approximately be $S=\left[A_{i}-\left[C_{i}-\left(C_{i}^{*} w_{t o t}\right)\right]+C_{i} * w_{s}\right] * T$. Generally, the equity finance is treated as the most expensive source of finance and the cost of debt finance is relatively cheaper than equity. As such, the premium or the compensation on $w_{s}$ required from the market (i.e. stockbroking business industry) due to the restrictions attached to collateral securities portfolio (as discussed above) would then become,

$$
E(S)=\left\{\left[\left(\beta_{u m}-\beta_{d}\right)+\left(R_{d} T\right) /\left(R_{m}-R_{f}\right)\right] D_{i o} / E_{i 0}\right\}\left(R_{m}-R_{f}\right)
$$

Where, the ratio $D_{i o} / E_{i 0}$ above is based on the optimal capital structure (if debtors were allowed). The most suitable proxy for this ratio, under regulatory restriction, is a similar industry average capital structure in the financial services industry. Finally, the collateral specific risk $w_{f}$ ultimately becomes a systematic component of risk required from the market, which is priced in the asset pricing regression model.

\section{RESEARCH METHOD AND ANALYSIS}

\section{Potential Growth Analysis}

In the sense of Higgins (1977, pp. 8-10) Potential Growth (G) of a firm can be determined using the following financial formula.

$$
\mathrm{G}=r(1+d) / a-[r\{1+d)]
$$

Where,

$$
\begin{aligned}
\mathrm{G}= & \text { Potential growth rate. } \\
\mathrm{a}= & \text { Assets / Sales Ratio, (assets required for a given amount of } \\
& \text { additional sales) } \\
\mathrm{r}= & \text { Retained earnings as a percentage of sales. } \\
\mathrm{d}= & \text { Debt / Equity ratio. }
\end{aligned}
$$

13 For managerial decision making, the present value would be more appropriate. 
Fifteen stockbrokerage firms were initially approached for collecting financial data. However, only eight firms had agreed to provide approximate ratios (financial ratios) between the line items in the financial statements (both income statement and the balance sheet), maintaining the anonymity ${ }^{14}$. None of the stockbrokerage firms had disclosed the actual financial figures (values or amounts) due to confidentiality issues. Based on the average ratios of the eight stockbrokerage firms, the following hypothetical financial performance and status for a stockbrokerage firm was developed. These financial figures therefore approximately coincide with the industry average $^{15}$.

\section{Example 01}

$\mathrm{ABC}$ Stockbrokers (Pvt) Ltd, wishes to increase its equity capital by $0.5 \mathrm{Mn}$ in order to provide credit to its investors.

\begin{tabular}{lcc}
\hline \multicolumn{1}{c}{ Line Item (Rs. millions) } & $\begin{array}{c}\text { Before Equity } \\
\text { Infusion (Rs.Mn) }\end{array}$ & $\begin{array}{c}\text { After Equity } \\
\text { Infusion (Rs.Mn) }\end{array}$ \\
\hline Revenue (sales) & 10 & 10.0032 \\
\hline Assets & 8 & 8.5000 \\
\hline Debt capital & 0 & 0 \\
\hline Equity & 1.67 & 2.1700 \\
\hline $\begin{array}{l}\text { Retained earnings (RE }=2.5 \mathrm{Mn}) \\
\text { as a percentage of sales }\end{array}$ & $25 \%$ & $25.92 \%$ \\
\hline
\end{tabular}

Notes:

1. The minimum capital requirement of $35 \mathrm{Mn}$ is ignored for a prudent analysis of the case.

2. Stockbrokerage is $0.64 \%$ on the total value of transactions. Assume, for instance, that there are no negotiable trades or day trading so that the brokerage of $0.64 \%$ does not change.

3. Assume that ABC Stockbrokers (Pvt) Ltd charges $18 \%$ as penalty income on the outstanding settlements over $\mathrm{T}+3$. Also, note that the debtors are accrued after $\mathrm{T}+3$.

4. It is assumed that additional earnings are re-invested in the firm's equity.

5. Preference shares if issued by the firm are also considered in the shareholder funds for the purpose of financial reporting and compliance, as per CSE stockbroker rules.

6. There is no debt in the firm's capital structure because the debt capital is not considered in the shareholder funds for the purpose of extension of credit.

7. The revenue is the brokerage income generated from trading on clients' funds (on clients' behalf) and the firm makes CDS net broker settlements on $T+3$. Assume that the firm does not utilize clients' funds for the purpose firm's operation, in line with the stockbroker rules.

14 I.e. by word of mouth, given the personal rapport maintained between members of the stockbrokerage firms.

15 Note that the amount or the value of line items in the example does not reflect the industry average; but the ratios between the line items provide a good approximation. Also, note that there are no publicly available financial statements of firms in the stockbroking industry in Sri Lanka. 
The following were apparent from the financial data provided,

1. Additional revenue as a result of extension of credit $0.5 \mathrm{Mn} \times 0.64 \%$ $=0.0032 \mathrm{Mn}$.

2. Penalty income on extension of credit $0.5 \mathrm{Mn} \times 18 \%=0.09 \mathrm{Mn}$ (other income)

3. Total equity after extension of credit $1.67 \mathrm{Mn}+0.50 \mathrm{Mn}=2.17 \mathrm{Mn}$

4. Total assets after extension of credit $8 \mathrm{Mn}+0.50 \mathrm{Mn}=8.5 \mathrm{Mn}$

5. Total retained earnings after extension of credit $2.5 \mathrm{Mn}+0.0032 \mathrm{Mn}$ $+0.09 \mathrm{Mn}=2.5932 \mathrm{Mn}$

Calculation of potential growth of ABC Stockbrokers (Pvt) Ltd

\begin{tabular}{lll}
\hline \multicolumn{1}{c}{ Ratio } & \multicolumn{1}{c}{$\begin{array}{c}\text { Before Equity Infusion } \\
\text { (Rs.Mn) }\end{array}$} & \multicolumn{1}{c}{$\begin{array}{c}\text { After Equity Infusion } \\
\text { (Rs.Mn) }\end{array}$} \\
\hline$a=$ Asset/Sales & $8 / 10=0.8$ & $8.5 / 10.0032=0.8500$ \\
\hline$r=$ RE/Sales & $2.5 / 10=0.25$ & $2.5932 / 10.0032=0.2592$ \\
\hline$d=D / E$ & $0.00 / 1.67=0.00$ & $0.00 / 2.17=0.00$ \\
\hline$G=r(I+d) / a-[r\{\mid+d)]$ & $45.45 \%$ & $43.87 \%$ \\
\hline
\end{tabular}

Since the total investment in credit is not entirely reflected in the total revenue of the firm (i.e. only $0.64 \%$ on the total investment), the return on equity $(\mathrm{ROE}){ }^{16}$ does not justify the asset base. As such, the rule of extension of credit to investors using permanent sources of capital restricts the growth potential of the firm.

Assume that the above firm is operating in any other industry, for example, manufacturing and export of goods - where the total amount of credit extended to customers is fully reflected in the revenue of the firm ${ }^{17}$. The potential growth $(\mathrm{G})$ is computed as follows.

1. Additional revenue as a result of extension of credit $=0.5 \mathrm{Mn}$.

2. Total revenue after extending credit to customers $=10.5 \mathrm{Mn}$

3. Total equity after extension of credit $1.67 \mathrm{Mn}+0.50 \mathrm{Mn}=2.17 \mathrm{Mn}$

4. Total assets after extension of credit $8 \mathrm{Mn}+0.50 \mathrm{Mn}=8.5 \mathrm{Mn}$

5. Total retained earnings after extension of credit $2.5 \mathrm{Mn}+0.5 \mathrm{Mn}=3 \mathrm{Mn}$.

16 I.e. shareholder value

17 It is assumed that no default of payments is encountered by the firm, except for the firm's inability to manage the collateral portfolio due to regulatory restrictions. 


\begin{tabular}{ll}
\multicolumn{1}{c}{ Ratio } & \multicolumn{1}{c}{ After Equity Infusion (Rs.Mn) } \\
\hline $\mathrm{a}=$ Asset/Sales & $8.5 / 10.5=0.8$ \\
\hline $\mathrm{r}=\mathrm{RE} /$ Sales & $3 / 10.50=0.2857$ \\
\hline $\mathrm{d}=\mathrm{D} / \mathrm{E}$ & $0.00 / 2.17=0.00$ \\
\hline $\mathrm{G}=\mathrm{r}(\mathrm{l}+\mathrm{d}) / \mathrm{a}-[\mathrm{r}\{\mathrm{l}+\mathrm{d})]$ & $54.54 \%$ \\
\hline $\begin{array}{l}\text { Note: } \\
\text { 1. Additional cost is assumed to have been covered by economies of scale (mass production and operation) as capacity } \\
\text { increase is } 5 \text { percent on total revenue. }\end{array}$ \\
$\begin{array}{l}\text { 2. } \\
\text { The calculation above omits any interest that can be charged from the customers on trade credit. The potential growth } \\
\text { rate would be much higher than the reported, if any interest on credit is recognized as income. }\end{array}$
\end{tabular}

It can easily be shown that - when compared with scenario one - there is a significant increment in the potential growth rate (i.e. by $9.09 \%$ ) of the firm.

\section{DuPont Analysis}

The following analysis was carried out using the figures given under example 01, except for change in capital structure of the firm.

\section{Example 2}

ABC Stockbrokers (Pvt) Ltd wishes to increase its equity capital by $0.5 \mathrm{Mn}$ in order to provide credits to its investors.

\begin{tabular}{lcc}
\hline Line Item (Rs. millions) & $\begin{array}{c}\text { Before Equity Infusion } \\
\text { (Rs.Mn) }\end{array}$ & $\begin{array}{c}\text { After Equity Infusion } \\
\text { (Rs.Mn) }\end{array}$ \\
\hline Revenue (sales) & 10 & 10.0032 \\
\hline Assets & 8 & 8.5000 \\
\hline Debt capital & 0 & 0 \\
\hline Equity including reserves & 4.25 & 4.75 \\
\hline $\begin{array}{l}\text { Net income } \\
1.5\end{array}$ & & 1.5932 \\
\hline
\end{tabular}

Penalty income on extension of credit $0.5 \mathrm{Mn} \times 18 \%=0.09 \mathrm{Mn}$ (other income).

Total net income after extension of credit $1.5 \mathrm{Mn}+0.0032 \mathrm{Mn}+$ $0.09 \mathrm{Mn}=1.5932 \mathrm{Mn}$. 
*Assumptions and notes given in example 01 remain same

DuPont Analysis for ABC Stockbrokers (Pvt) Ltd

\section{Before Equity Infusion}

Net Profit Margin: Net Income $(1.5 \mathrm{Mn}) \div$ Revenue $(10 \mathrm{Mn})=15 \%$

Asset Turnover: Revenue $(10 \mathrm{Mn}) \div$ Assets $(8)=1.25$

Equity Multiplier: Assets $(8 \mathrm{Mn}) \div$ Shareholders' Equity $(4.25 \mathrm{Mn})=$ 1.88

Multiplication of three components together to calculate the return on equity:

Return on Equity: $(0.15) \times(1.25) \times(1.88)=\mathbf{0 . 3 5 2 5}$, or $\mathbf{3 5 . 2 5 \%}$

\section{After Equity Infusion}

Net Profit Margin: Net Income $(1.5932 \mathrm{Mn}) \div$ Revenue $(10.0032 \mathrm{Mn})$ $=15.92 \%$

Asset Turnover: Revenue $(10.0032 \mathrm{Mn}) \div$ Assets $(8.5 \mathrm{Mn})=1.17$

Equity Multiplier: Assets $(8.5 \mathrm{Mn}) \div$ Shareholders' Equity $(4.75 \mathrm{Mn})$ $=1.78$

Multiplication of three components together to calculate the return on equity:

Return on Equity: $(0.1592) \times(1.17) \times(1.78)=\mathbf{0 . 3 3 1 5}$, or $\mathbf{3 3 . 1 5 \%}$

Assume that the above firm is operating in any other industry, for example, manufacturing and export of goods - other than services sector finance companies - where the total amount of credit extended to customers is fully reflected in the revenue of the firm. The same analysis is carried out as follows. 
Additional revenue as a result of extension of credit $=0.5 \mathrm{Mn}$.

Total revenue after extending credit to customers $=10.5 \mathrm{Mn}$.

Net income after extension of credit $1.5 \mathrm{Mn}+0.5 \mathrm{Mn}=2 \mathrm{Mn}$

Again, assume that the additional cost is covered by economies of scale as explained above.

\section{DuPont Analysis using above information}

After Equity Infusion

Net Profit Margin: Net Income $(2 \mathrm{Mn}) \div$ Revenue $(10.5 \mathrm{Mn})=19 \%$

Asset Turnover: Revenue $(10.5 \mathrm{Mn}) \div$ Assets $(8.5 \mathrm{Mn})=1.23$ $=1.78$

Equity Multiplier: Assets $(8.5 \mathrm{Mn}) \div$ Shareholders' Equity $(4.75 \mathrm{Mn})$

Multiplication of three components together to calculate the return on equity:

Return on Equity: $(0.19) \times(1.23) \times(1.78)=\mathbf{0 . 4 1 5 9}$, or $\mathbf{4 1 . 5 9 \%}$

According to the analysis above, it is clear that the extension of credit to clients using permanent source of equity capital is contradictory with the shareholder wealth maximization concept.

\section{Further Explanations}

Why there is no incremental benefit in ROE.?

1. The firms lose the opportunity to maintain the best capital mix (the optimal capital structure at the breakeven cost of capital (i.e. WACC)) because the tax advantage on interest cost is forgone.

2. The funds (financed by issue of equity) tying up in assets (i.e. in debtors) do not produce an adequate return (i.e. brokerage income) for its residency period. 
3. Since there is thirty (30) calendar days exemption for deducting debtors from shareholder funds, the maximum number of times that Rs. $0.5 \mathrm{Mn}$ can be utilized to trade to earn additional revenue (i.e. brokerage) is 24times (12times x 2); both purchase and sales side ${ }^{18}$.

The following analysis proves that there are no significant incremental benefits in ROE and potential growth even if the firm trades as in (3) above.

Potential Growth Analysis - ABC Stockbrokers (Pvt) Ltd

1. Additional revenue as a result of extension of credit $0.5 \mathrm{Mn} \times 0.64 \%$ x $24=0.0768 \mathrm{Mn}$

2. Penalty income on extension of credit $0.5 \mathrm{Mn} \times 18 \%=0.09 \mathrm{Mn}$ (other income)

3. Total retained earnings after extension of credit $2.5 \mathrm{Mn}+0.0768 \mathrm{Mn}$ $+0.09 \mathrm{Mn}=1.6668 \mathrm{Mn}$.

4. Other notes given in example remain same

$$
G=r(l+d) / a-[r\{1+d)] \quad \mathbf{4 5 . 7 0 \%} \text { (increment }=\mathbf{0 . 2 5 \%})
$$

DuPont Analysis - ABC Stockbrokers (Pvt) Ltd

1. Additional revenue as a result of extension of credit $0.5 \mathrm{Mn} \times 0.64 \%$ x $24=0.0768 \mathrm{Mn}$.

2. Penalty income on extension of credit $0.5 \mathrm{Mn} \times 18 \%=0.09 \mathrm{Mn}$ (other income)

3. Total net income after extension of credit $1.5 \mathrm{Mn}+0.0768 \mathrm{Mn}+0.09 \mathrm{Mn}$ $=1.6668 \mathrm{Mn}$.

4. Other notes given in example remain same

18 Note that, once advanced as 'credits', such portfolio is not traded until fully settled. Practically, trading on credit for speculative reasons is possible in highly active markets. It is likely that frequent trading under ' dull' market conditions, unless possessing insider information, results in losses. This adds an additional stress to managers to increase sales turnover by increasing stock trades of clients. More importantly, this will create ethical issues and conflict of interest on trading. 
Net Profit Margin: Net Income $(1.6668 \mathrm{Mn}) \div$ Revenue $(10.0768 \mathrm{Mn})$ $=16.54 \%$

Asset Turnover: Revenue $(10.0768 \mathrm{Mn}) \div$ Assets $(8.5 \mathrm{Mn})=1.18$

Equity Multiplier: Assets $(8.5 \mathrm{Mn}) \div$ Shareholders' Equity $(4.75 \mathrm{Mn})$ $=1.78$

Multiplication of three components together to calculate the return on equity:

Return on Equity: $(0.1654) \times(1.18) \times(1.78)=\mathbf{0 . 3 4 7 4}$, or $\mathbf{3 4 . 7 4 \%}$

\section{LIMITATIONS OF THE STUDY}

Although the sample of the study included fifteen stockbrokerage firms, only eight stockbrokerage firms had agreed to provide necessary information. As such, the average financial ratios of eight firms out of fifteen member firms were taken as a representative sample for the industry average. It should be noted that, the issue of representativeness does not have a significant impact on the conclusions, because this case study is about the regulatory restrictions on the performance of stockbrokerage firms ${ }^{19}$.

On the other hand, some stockbrokerage firms are affiliated with large banks or financial institutions (i.e stockbroking is a part of their business portfolio) that have diversified portfolio of businesses. As such, the deterioration of shareholder value due to regulatory restrictions may not collectively be significant for the group business (i.e. the shareholders of the group) as these adverse financial consequences could be set-aside by other profitable operations of such institutions. The above case is therefore applicable to unaffiliated stockbrokerage firms.

19 I.e. not about the operational differences among stockbrokerage firms. 


\section{CONCLUSIONS}

Deduction of debtors (i.e. current assets) from the shareholder funds (in ascertaining net capital) brings adverse consequences in terms of operation, financing and working capital management - it restricts the growth potential of a stockbroker. A stockbrokerage firm is therefore unable to maintain its optimal capital structure which returns the firm commensurate with the risk accepted by its ordinary (equity) shareholders. If the return on equity and potential growth of the firm are reduced as a result of infusing capital (shareholder funds) for the purpose of investing in current assets (debtors), the shareholders will find themselves deteriorating their value. Further, ROE and the potential growth are reduced substantially after compliance with the regulation. However, the results are significantly different when applied to other industries such as manufacturing and exports (when the credits extended or credit sales are fully reflected in the revenue).

These adverse consequences are apparent given the fact that the amount utilized (amount utilized from equity capital raised) for extending credits to clients is not fully reflected in the revenue of the firm (only a percentage, i.e. $0.64 \%$, is reflected in the revenue). This is not applicable to other firms (e.g. manufacturing firms) because the credit extended from equity capital is fully reflected in the revenue and the collateral portfolio is not a part of credit portfolio of those firms. The regulation restricts the firm's attempt to diversify the collateral portfolios in the market in order to reduce the systematic risk attached to the securities in the collateral portfolio. In this case, the firm foregoes tax savings on potential diversification benefits of collateral securities portfolio and, as such, the stockholders of stockbrokerage firms require compensation from the stockbroking market (i.e. diversifiable risk becomes a systematic risk which is priced). These regulatory restrictions add an additional stress level to corporate management to leverage the number of times of sales (sales turnover) in order to overcome the issue, which may result in overtrading. Also, it may create ethical issues on soliciting clients and inducing them to trade in the stock market, without proper justifications. Along these lines, Fernando et al., (2016) show that stockbroker advice significantly impacts investor behavior. As such, policymakers should take into account the above factors when policy decisions are made for the financial services industry. 


\section{DISCLAIMER}

The views expressed in this article are those of the authors and do not necessarily reflect the views of the stockbrokerage firms or authors' affiliations.

\section{ACKNOWLEDGEMENT}

The authors would like to thank the members of the editorial board and two unknown reviewers for helpful comments. This paper substantially reflects the first author's expression of interest submitted to the Colombo Stock Exchange in September 2012 (See Senarathne, 2012). All remaining errors are the authors' responsibility.

\section{REFERENCES}

Abor, J. (2005). The effect of capital structure on profitability: An empirical analysis of listed firms in Ghana. The Journal of Risk Finance, 6(5), 438-445.

Afrifa, G. A., \& Padachi, K. (2016). Working capital level influence on SME profitability. Journal of Small Business and Enterprise Development, 23(1), 44-63.

Afza, T., \& Nazir, M. S. (2007). Is it better to be aggressive or conservative in managing working capital. Journal of Quality and Technology Management, 3(2), 11-21.

Afza, T., \& Nazir, M. S. (2008). Working capital approaches and firm's returns. Pakistan Journal of Commerce and Social Sciences, 1(1), 25-36.

Aktas, N., Croci, E., \& Petmezas, D. (2015). Is working capital management value-enhancing? Evidence from firm performance and investments. Journal of Corporate Finance, 30, 98-113.

Chadha, S., \& Sharma, A. K. (2015). Capital structure and firm performance: Empirical evidence from India. Vision, 19(4), 295-302. 
Chiou, J. R., Cheng, L., \& Wu, H. W. (2006). The determinants of working capital management. Journal of American Academy of Business, 10(1), 149-155.

Chung, T., \& Mohd, A. (2018). Whither competition in Malaysia's banking industry ex post a restructuring. Journal of Economic Studies, 45(2), 263-282.

DeGeest, D. S., Rink, F., \& Stoker, J. I. (2016). Gender composition, flexible working arrangements, and new venture performance: A moderated model. In Academy of Management Proceedings (Vol. 2016, No. 1, p. 15647). Briarcliff Manor, NY 10510: Academy of Management.

Enqvist, J., Graham, M., \& Nikkinen, J. (2014). The impact of working capital management on firm profitability in different business cycles: Evidence from Finland. Research in International Business and Finance, 32, 36-49.

Fah, C. T., \& Ariff, M. (2017). Competition in the Malaysia's banking industry, Quo Vadis. International Journal of Economics \& Management, 53(11), 897-920.

Fernando, C. S. P. K., Weerasinghe, W. D. J. D., Perera, L. A. S. \& Weerarathne, D. I. (2016). Factors affecting the behavior of investors: Empirical study based on Colombo stock exchange. Paper presented at the 7th International Conference on Business \& Information ICBI - 2016, Faculty of Commerce and Management Studies, University of Kelaniya.

Freedi, A. A., Shamiri, A., \& Isa, Z. (2012). A study on the behavior of volatility in Saudi Arabia stock market using symmetric and asymmetric GARCH models. Journal of Mathematics and Statistics, 8(1), 98-106

Goudarzi, H., \& Ramanarayanan, C. S. (2011). Modeling asymmetric volatility in the Indian stock market. International Journal of Business and Management, 6(3), 221-231.

Higgins, R. C. (1977). How much growth can a firm afford?. Financial Management, 6(3), 7-16. 
Iqbal, A., \& Zhuquan, W. (2015). Working capital management and profitability evidence from firms listed on Karachi Stock Exchange. International Journal of Business and Management, 10(2), 231.

Jose, M. L., Lancaster, C., \& Stevens, J. L. (1996). Corporate returns and cash conversion cycles. Journal of Economics and Finance, 20(1), $33-46$.

Kadirgamar, A. (2012, August 26). Stock Market Crisis and Oligarchic Interests, Colombo Telegraph. Retrieved from https://www.colombot elegraph.com/index.php/stock-market-crisis-and-oligarchic-interests/

Kieschnick, R., Laplante, M., \& Moussawi, R. (2013). Working capital management and shareholders' wealth. Review of Finance, 17(5), 1827-1852.

Kim, Y. H., \& Chung, K. H. (1990). An integrated evaluation of investment in inventory and credit: A cash flow approach. Journal of Business Finance \& Accounting, 17(3), 381-389.

Leite, P., \& Cortez, M. C. (2015). Performance of European socially responsible funds during market crises: Evidence from France. International Review of Financial Analysis, 40, 132-141.

Lim, K. P., Brooks, R. D., \& Kim, J. H. (2008). Financial crisis and stock market efficiency: Empirical evidence from Asian countries. International Review of Financial Analysis, 17(3), 571-591.

Lyngstadaas, H., \& Berg, T. (2016). Working capital management: evidence from Norway. International Journal of Managerial Finance, 12(3), 295-313.

Miller, M. H. (1977). Debt and taxes. The Journal of Finance, 32(2), 261275.

Mishkin, F. S. (1992). Anatomy of a financial crisis. Journal of Evolutionary Economics, 2(2), 115-130. 
Muhammad, H., Rehman, A. U., \& Waqas, M. (2016). The relationship between working capital management and profitability: A case study of Tobacco industry of Pakistan. The Journal of Asian Finance, Economics and Business, 3(2), 13-20.

Padachi, K. (2006). Trends in working capital management and its impact on firms' performance: An analysis of Mauritian small manufacturing firms. International Review of Business Research Papers, 2(2), 45-58.

Pais, M. A., \& Gama, P. M. (2015). Working capital management and SMEs profitability: Portuguese evidence. International Journal of Managerial Finance, 11(3), 341-358.

Reuters (2011, October 19). Stock market crashes to lowest level in 2011. Daily Financial Times. Retrieved from http://www.ft.lk/article/52671/ Stock-market-crashes-to-lowest-level-in-2011

Reuters (2012, January 18). Brokers to submit net capital statement monthly. Daily Financial Times. Retrieved from http://www.ft.lk/article/6 6781/ Brokers-to-submit-net-capital-statement-monthly

Samiloglu, F., \& Akgün, A. İ. (2016). The relationship between working capital management and profitability: Evidence from Turkey. Business and Economics Research Journal, 7(2), 1-14.

Schiff, M., \& Lieber, Z. (1974). A model for the integration of credit and inventory management. The Journal of Finance, 29(1), 133-140.

Senarathne, C. W. (2012). Risk adjusted net capital and broker credit: A risk based approach. Unpublished expression of interest.

Shubik, M. (2016). Three essays on the theory of money and financial institutions: Essay 1: A Nontechnical Overview. (Cowles Foundation Discussion Paper No. 2036R). Retrieved from https://cowles.yale.edu/ sites/default/files/files/pub/d20/d2036-r.pdf

Singh, H. P., Kumar, S., \& Colombage, S. (2017). Working capital management and firm profitability: a meta-analysis. Qualitative Research in Financial Markets, 9(1), 34-47. 
Smith, K. (1980). Profitability versus liquidity tradeoffs in working capital management. Readings on the Management of Working Capital, 42, 549-562.

Titman, S. (2002). The Modigliani and Miller theorem and the integration of financial markets. Financial Management, 31(1), 101-115.

Titman, S., \& Wessels, R. (1988). The determinants of capital structure choice. The Journal of Finance, 43(1), 1-19.

Toniolo, G., Conte, L., \& Vecchi, G. (2003). Monetary Union, institutions and financial market integration: Italy, 1862-1905. Explorations in Economic History, 40(4), 443-461.

Transparency International Sri Lanka (2012, August 1). Manipulation in the Sri Lankan stock market. Daily Mirror. Retrieved from http://www. dailymirror.lk/20787/manipulation-in-the-sri-lankan-stock-market

Wang, Y. J. (2002). Liquidity management, operating performance, and corporate value: Evidence from Japan and Taiwan. Journal of Multinational Financial Management, 12(2), 159-169.

Yin, X. (2004). Two-part tariff competition in duopoly. International Journal of Industrial Organization, 22(6), 799-820. 